\title{
Anthropometric Profile and Diabetic Foot Risk: A Cross-Sectional Study Using Thermography
}

Conference Paper · August 2015

DOI: 10.1109/EMBC.2015.7445519

CITATIONS

0

6 authors, including:

\section{Eduardo Borba Neves}

Exército Brasileiro

158 PUBLICATIONS 239 CITATIONS

SEE PROFILE

\section{Victor Machado Reis}

Universidade de Trás-os-Montes e Alto Douro 277 PUBLICATIONS 1,022 CITATIONS

SEE PROFILE
José Vilaça Alves

Universidade de Trás-os-Montes e Alto Douro 77 PUBLICATIONS 195 CITATIONS

SEE PROFILE

\section{Romeu Mendes}

Universidade de Trás-os-Montes e Alto Douro 143 PUBLICATIONS 136 CITATIONS

SEE PROFILE

Some of the authors of this publication are also working on these related projects: 


\title{
Anthropometric Profile and Diabetic Foot Risk: A Cross-Sectional Study Using Thermography
}

\author{
Eduardo B. Neves, António J. Almeida, Claudio Rosa, José Vilaça-Alves, Victor M. Reis and Romeu \\ Mendes
}

\begin{abstract}
Diabetes is one of the greatest todays public health problems with enormous social and economic implications for society. Diabetic foot disorders represent a substantial economic burden with detrimental effects on quality of life with special impairment in physical domain. Early detection strategies of these complications should be implemented in order to avoid possible wounds, ulcerations and amputations. This work can be characterized as a crosssectional study with an analytical approach. It involved 44 volunteers of both genders ( 22 women and 22 men; $66.70 \pm 6.26$ years of age) with type 2 diabetes (diagnosed at $11.84 \pm 8.22$ years), selected among the candidates to Diabetes em Movimento $^{\circledR}$ (a community-based exercise program for patients with type 2 diabetes developed in the city of Vila Real, Portugal). Foot plantar thermal images were acquired through a high-resolution infrared camera (FLIR Systems Inc. Model SC2000; $320 \times 240$ pixels). Three regions of interest (ROI) were defined for evaluation: first finger, fifth finger and the heel. From the three pairs of ROIs evaluated, the higher temperature asymmetry was selected for diabetic foot risk analysis. The results showed the existence of a positive and significant association between BMI and fat mass with asymmetries in feet temperature. Three subjects with diabetesrelated foot complications (ROIs higher temperature asymmetry $\geq 2.20{ }^{\circ} \mathrm{C}$ ) were identified in the sample. All participants with detected diabetes-related foot complications were obese (BMI $\left.\geq 30 \mathrm{~kg} / \mathrm{m}^{2}\right)$ with high levels of body fat $(\geq$ $45 \%)$. It can be concluded that exist a positive association either of BMI $(r=0.399, p=0.007)$ either of body fat percentage $(r=0.432, p=0.003)$, with diabetic foot risk in patients with type 2 diabetes.
\end{abstract}

\section{INTRODUCTION}

Diabetes is one of the greatest todays public health problems with enormous social and economic implications for society $[1,2]$. Diabetic foot disorders represent a substantial economic burden with detrimental effects on quality of life with special impairment in physical domain [3]. Early detection strategies of these complications should be implemented in order to avoid possible wounds, ulcerations and amputations [4]. The evaluation of factors

*This research supported by Portuguese Foundation for Science and Technology (FCT)

Eduardo. B. Neves - Brazilian Army; Graduate Program in Biomedical Engineering, Federal Technological University of Paraná; Brazil (borbaneves@hotmail.com).

António Almeida, Cláudio Rosa, José Vilaça-Alves, Victor M. Reis and Romeu Mendes - Research Center in Sports Sciences, Health Sciences and Human Development (CIDESD); University Trás-os-Montes e Alto Douro, Vila Real, Portugal.

Romeu Mendes - Public Health Unit, ACES Douro I - Marão e Douro Norte; Vila Real, Portugal. associated with increased risk of diabetic foot is also important [5].

Thermography has been used as a diagnostic tool for various disorders: cancer diagnosis [6], carpal tunnel syndrome[7], complex regional pain syndrome[8], muscle damage diagnosis $[9,10]$, and evaluation of muscle recovery[11], and also to evaluate diabetic foot risk and diabetes-related foot complications already established [1214].

Authors have reported that obesity is a major risk factor for the development of the diabetic foot $[15,16]$. The body mass index (calculated from the body mass and height) and the percentage of fat are among the obesity indicators most commonly used in the literature $[17,18]$. In this sense, this study aimed to analyze the association between the anthropometric profile (body mass, body height, body mass index and body fat) and diabetic foot risk in patients with type 2 diabetes, assessed through digital infrared thermal imaging technique.

\section{METHOD}

\section{A. Study design and Sample}

This work can be characterized as a cross-sectional study with an analytical approach. It involved 44 volunteers of both genders ( 22 women and 22 men; $66.70 \pm 6.26$ years of age) with type 2 diabetes (diagnosed at $11.84 \pm 8.22$ years), selected among the candidates to Diabetes em Movimento ${ }^{\circledR}$ (a community-based exercise program for patients with type 2 diabetes developed in the city of Vila Real, Portugal [19]) according with the following inclusion criteria: type 2 diabetes diagnosed at least one year; without active foot wounds or ulcers; community-dwelling; non-smokers; without major cardiovascular, pulmonary, musculoskeletal, renal, and neurological disease; and signed informed consent. The experimental procedures involving human subjects described in this paper were approved by the Institutional Review Board

\section{B. Instrumentation and Data Acquisition}

Body mass and body fat were assessed by bioelectrical impedance analysis technique (Tanita, $B C-418 \mathrm{MA}$ ) on fasting state conditions. Body height was measured with a stadiometer $(S E C A, 220)$ with a graduation of $0.5 \mathrm{~cm}$.

Foot plantar thermal images were acquired through a high-resolution infrared camera (FLIR Systems Inc. Model SC2000; 320 x 240 pixels). This instrument measures temperatures ranging from $-20^{\circ} \mathrm{C}$ to $+120^{\circ} \mathrm{C}$ with sensitivity 
to detect differences of less than $0.1{ }^{\circ} \mathrm{C}$, and accuracy of \pm 1 ${ }^{\circ} \mathrm{C}$ of the absolute temperature.

In order to monitor the laboratory's temperature $(20 \pm 1$ ${ }^{\circ} \mathrm{C}$ ) and humidity $(55 \%)$, a digital thermohygrometer was used.

\section{Data Analysis}

Body mass and body height were used to calculate body mass index (BMI).

Thermal images were analyzed using the software ThermaCam $^{T M}$ Researcher Pro 2.9 (FLIR Systems Inc.). Three regions of interest (ROI) were defined for evaluation: first finger, fifth finger and the heel, as illustrated in Figure 1. The average of ROI temperature was considered for the analyses. For each pair of ROI (e.g. AR01 and AR02 in Figure 1) skin temperature difference (asymmetry) was calculated for each volunteer. From the three pairs of ROIs evaluated, the higher temperature asymmetry was selected for diabetic foot risk analysis. A cut-off difference of $2.2^{\circ} \mathrm{C}$ was used to detect diabetes-related foot complications [20].

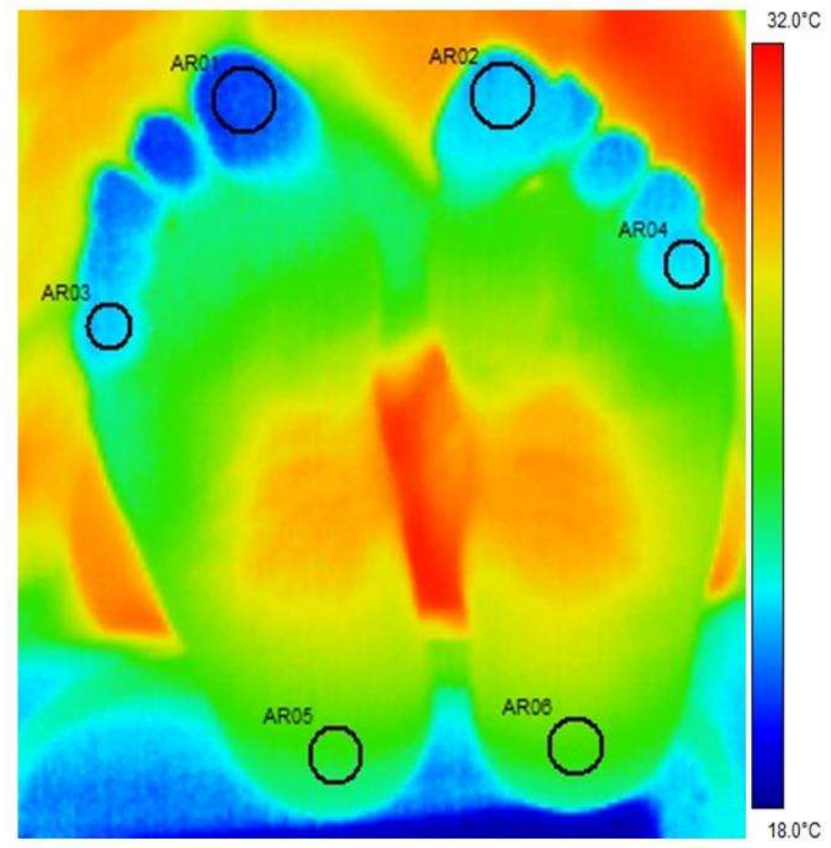

Figure 1. Illustration of plantar foot thermal images analysis protocol. The circles indicate the regions of interest (ROI).

\section{Statistical Analysis}

Pearson's correlations were used to evaluate the association between anthropometric profile variables (body mass, body height, BMI and body fat) and the higher temperature asymmetry (among the three pairs of ROIs evaluated). The statistical analyses were carried out with software Statistical Package for Social Sciences (IBM SPSS, version 21.0). The statistical significance level was defined as $p<0.05$

\section{RESULTS}

Anthropometric profile variables and ROIs temperature values are presented in Table I. All volunteers were righthanded.

TABLE I. ANTHROPOMETRIC AND THERMAL VARIABLES (N=44)

\begin{tabular}{|l|c|c|}
\hline \multicolumn{1}{|c|}{ Variables } & Average & SD \\
\hline Body mass $(\mathrm{kg})$ & 77.95 & 10.94 \\
\hline Body height $(\mathrm{m})$ & 1.62 & 0.09 \\
\hline Body mass index $\left(\mathrm{kg} / \mathrm{m}^{2}\right)$ & 29.66 & 3.52 \\
\hline Body fat $(\%)$ & 36.74 & 8.04 \\
\hline Right first finger skin temperature $\left({ }^{\circ} \mathrm{C}\right)$ & 20.82 & 1.89 \\
\hline Left first finger skin temperature $\left({ }^{\circ} \mathrm{C}\right)$ & 20.45 & 1.79 \\
\hline Right fifth finger skin temperature $\left({ }^{\circ} \mathrm{C}\right)$ & 21.47 & 2.32 \\
\hline Left fifth finger skin temperature $\left({ }^{\circ} \mathrm{C}\right)$ & 21.01 & 1.85 \\
\hline Right heel skin temperature $\left({ }^{\circ} \mathrm{C}\right)$ & 22.86 & 1.69 \\
\hline Left heel skin temperature $\left({ }^{\circ} \mathrm{C}\right)$ & 22.79 & 1.34 \\
\hline
\end{tabular}

SD, standard deviation.

Table II presents the Pearson's correlation coefficients between anthropometric variables and the higher temperature asymmetry (among the three pairs of ROIs evaluated).

TABLE II. PEARSON'S CORRELATION COEFFICIENTS BETWEEN ANTHROPOMETRIC PROFILE VARIABLES AND THE HIGHER TEMPERATURE ASYMMETRY $(\mathrm{N}=44)$.

\begin{tabular}{|l|c|c|}
\hline \multicolumn{1}{|c|}{ Variables } & r & $\boldsymbol{p}$ \\
\hline Body mass x higher temperature asymmetry & 0.188 & 0.223 \\
\hline Body height x higher temperature asymmetry & -0.175 & 0.256 \\
\hline Body mass index x higher temperature asymmetry & $0.399^{*}$ & 0.007 \\
\hline Body fat percentage x higher temperature asymmetry & $0.432^{*}$ & 0.003 \\
\hline
\end{tabular}

* statistical significance

Three subjects with risk of diabetes-related foot complications (ROIs higher temperature asymmetry $\geq 2.20$ ${ }^{\circ} \mathrm{C}$ ) were found (Table III).

TABLE III. AGE AND ANTHROPOMETRIC PROFILE OF THE VOLUNTEERS WITH DIABETES-RELATED FOOT COMPLICATIONS.

\begin{tabular}{|c|c|c|c|c|}
\hline $\begin{array}{c}\text { Volunteer } \\
\text { code }\end{array}$ & $\begin{array}{c}\text { Age } \\
\text { (years) }\end{array}$ & $\begin{array}{c}\text { ROI / higher } \\
\text { temperature } \\
\left.\text { asymmetry ( }{ }^{\mathbf{C}} \mathbf{C}\right)\end{array}$ & $\begin{array}{c}\text { BMI } \\
\left(\mathbf{k g} / \mathbf{m}^{\mathbf{2}}\right)\end{array}$ & $\begin{array}{c}\text { Body } \\
\text { Fat (\%) }\end{array}$ \\
\hline 6 & 59 & fifth finger / 3.4 & 31.62 & 45.90 \\
\hline 16 & 79 & fifth finger / 2.2 & 31.69 & 46.40 \\
\hline 23 & 58 & first finger / 5.9 & 37.18 & 52.40 \\
\hline \multicolumn{5}{|c}{ ROI, region of interest; BMI, body mass index. } \\
\hline
\end{tabular}




\section{DISCUSSION}

This study applied a plantar foot thermographic analysis protocol to evaluate the association between diabetic foot risk and anthropometric profile in patients with type 2 diabetes. Volunteers presented typical age and anthropometric profile of these population: aged individuals with overweight and obesity. The results showed the existence of a positive and significant association between BMI and fat mass with asymmetries in feet temperature. These contralateral asymmetries have been used to predict diabetic foot risk and detect diabetes-related foot complications [13, 20]. Besides increasing the risk of coronary artery disease and cerebrovascular disease [21], obesity can also increase the risk of peripheral arterial disease and microvascular complications such as peripheral neuropathy predisposing for diabetes-related foot problems.

The increase in the plantar pressure among obese people (because of increased body mass) can lead to changes in bone structure and tissue, changes in posture and gait. The increase in the plantar pressure is associated with the development of ulcers which can increase the risk of amputation[22]. All participants with detected diabetes-related foot complications were obese $\left(\mathrm{BMI} \geq 30 \mathrm{~kg} / \mathrm{m}^{2}\right)$ with high levels of body fat $(\geq$ $45 \%)$. Although other risk factors has not been investigated, obesity is usually associated with physical inactivity, poor diet, high blood pressure, inadequate metabolic control, alcoholism, smoking, sensitivity commitment to plant and lack of foot care[15]. Body mass control should be a priority in these patients either for metabolic control of diabetes, either for reducing the risk of associated complications such as diabetic foot.

\section{CONCLUSION}

It can be concluded that exist a positive association either of BMI $(r=0.399, p=0.007)$ either of body fat percentage $(\mathrm{r}=0.432, \mathrm{p}=0.003)$, with diabetic foot risk in patients with type 2 diabetes.

\section{ACKNOWLEDGMENT}

The authors would like to acknowledge to Diabetes em Movimento $^{\circledR}$ research team and participants. And we also would like to thank Brazilian Army and Brazilian Counsel of Technological and Scientific Development (CNPq) by the Eduardo B. Neves scholarship. And we would like to thank $\mathrm{CNPq}$ and Araucaria Foundation for financial support to our participation in this event.

\section{REFERENCES}

[1] World Health Organization, "GLOBAL STATUS REPORT on noncommunicable diseases 2014," World Health Organization, Geneva2014.

[2] T. Seuring, O. Archangelidi, and M. Suhrcke, "The Economic Costs of Type 2 Diabetes: A Global Systematic Review," PharmacoEconomics, 2015.

[3] K. van Acker, P. Leger, A. Hartemann, A. Chawla, and M. K. Siddiqui, "Burden of diabetic foot disorders, guidelines for management and disparities in implementation in Europe: a systematic literature review," Diabetes Metab Res Rev, vol. 30, pp. 635-45, Nov 2014.

[4] K. Bakker, J. Apelqvist, and N. C. Schaper, "Practical guidelines on the management and prevention of the diabetic foot 2011," Diabetes Metab Res Rev, vol. 28 Suppl 1, pp. 225-31, Feb 2012.

[5] A. J. M. Boulton, D. G. Armstrong, S. F. Albert, R. G. Frykberg, R. Hellman, M. S. Kirkman, et al., "Comprehensive Foot Examination and Risk Assessment," Diabetes Care, vol. 31, pp. 1679-1685, 2008.

[6] S. S. Suganthi and S. Ramakrishnan, "Analysis of Breast Thermograms Using Gabor Wavelet Anisotropy Index," Journal of Medical Systems, vol. 38, pp. 1-7, 2014.

[7] V. Magas, E. B. Neves, M. A. M. d. Moura, and P. Nohama, "Avaliação da aplicação da termografia no diagnóstico de LER-DORT de punho," in XXIII Congresso Brasileiro em Engenharia Biomédica, Porto de Galinhas - PE, Brazil, 2012, pp. 583-586.

[8] G. Gradl, M. Steinborn, I. Wizgall, T. Mittlmeier, and M. Schurmann, "Acute CRPS I (Morbus sudeck) following distal radial fractures Methods for early diagnosis," Zentralblatt Fur Chirurgie, vol. 128, pp. 1020-1026, 2003

[9] F. Bandeira, E. B. Neves, M. A. M. d. Moura, and P. Nohama, "A termografia no apoio ao diagnóstico de lesão muscular no esporte," Rev. Bras. Med. Esporte, vol. 20, pp. 59-64, 2014

[10] F. Bandeira, M. A. M. d. Moura, M. A. d. Souza, P. Nohama, and E. B. Neves, "Pode a termografia auxiliar no diagnóstico de lesões musculares em atletas de futebol?," Rev. Bras. Med. Esporte, vol. 18, pp. 246-251, 2012.

[11] E. B. Neves, T. R. Moreira, R. J. C. A. d. Lemos, J. Vilaça-Alves, and V. M. Reis, "The Thermal Response of Biceps Brachii to Strength Training," Gazzetta Medica Italiana Archivio per le Scienze Mediche, vol. 174, p. In Press, 2015.

[12] S. Bagavathiappan, J. Philip, T. Jayakumar, B. Raj, P. N. Rao, M. Varalakshmi, et al., "Correlation between plantar foot temperature and diabetic neuropathy: a case study by using an infrared thermal imaging technique," J Diabetes Sci Technol, vol. 4, pp. 1386-92, Nov 2010.

[13] J. J. van Netten, J. G. van Baal, C. Liu, F. van der Heijden, and S. A. Bus, "Infrared thermal imaging for automated detection of diabetic foot complications," J Diabetes Sci Technol, vol. 7, pp. 1122-9, Sep 2013.

[14] K. Pafili and N. Papanas, "Thermography in the follow up of the diabetic foot: best to weigh the enemy more mighty than he seems," Expert Rev Med Devices, vol. 12, pp. 131-133, 2015.

[15] J. E. W. Boell, R. M. Ribeiro, and D. M. G. V. da Silva, "Fatores de risco para o desencadeamento do pé diabético," Revista Eletrônica de Enfermagem, vol. 16, pp. 386-93, 2014.

[16] C. A. M. d. Silva, D. d. S. Pereira, D. S. d. C. Almeida, and M. I. L. Venâncio, "Pé diabético e avaliação do risco de ulceração," Revista de Enfermagem Referência, vol. IV, pp. 153-161, 2014.

[17] E. B. Neves, "Prevalência de sobrepeso e obesidade em militares do exército brasileiro: associação com a hipertensão arterial," Ciên Saúde Coletiva, vol. 13, pp. 1661-8, 2008

[18] E. B. Neves, W. L. Ripka, L. Ulbricht, and A. M. W. Stadnik, "Comparison of the fat percentage obtained by bioimpedance, ultrasound and skinfolds in young adults," Rev. Bras. Med. Esporte, vol. 19, pp. 323-327, 2013

[19] R. Mendes, N. Sousa, V. M. Reis, and J. L. Themudo Barata, "Diabetes em Movimento® - Community-based exercise program for patients with type 2 diabetes," Br J Sports Med vol. 47, p. e3.43, 2013.

[20] J. J. van Netten, M. Prijs, J. G. van Baal, C. Liu, F. van der Heijden, and S. A. Bus, "Diagnostic values for skin temperature assessment to detect diabetes-related foot complications," Diabetes Technol Ther, vol. 16, pp. 714-21, 2014

[21] L. Ryden, P. J. Grant, S. D. Anker, C. Berne, F. Cosentino, N. Danchin, et al., "ESC Guidelines on diabetes, pre-diabetes, and cardiovascular diseases developed in collaboration with the EASD: The Task Force on diabetes, pre-diabetes, and cardiovascular diseases of the European Society of Cardiology (ESC) and developed in collaboration with the European Association for the Study of Diabetes (EASD)," Eur Heart J, vol. 34, pp. 3035-87, 2013.

[22] P. Cavanagh and J. Ulbrecht, "Clinical plantar pressure measurement in diabetes: rationale and methodology," The Foot, vol. 4, pp. 123135, 1994. 